\title{
Host use by Philornis sp. in a passerine community in central Argentina
}

\section{Uso de hospedadores por Philornis sp. en una comunidad de aves paseriformes de la parte central de Argentina}

\author{
Martín A. Quiroga ${ }^{1 凶}$, Juan C. Reboreda ${ }^{2}$ and Adolfo H. Beltzer ${ }^{1}$ \\ ${ }^{1}$ Instituto Nacional de Limnología (INALI-CONICET-UNL), Santa Fe, 3000 Santa Fe, Argentina. \\ ${ }^{2}$ Departamento de Ecología, Genética y Evolución, Facultad de Ciencias Exactas y Naturales, Universidad de Buenos Aires, Pabellón II Ciudad \\ Universitaria, C1428EGA Buenos Aires, Argentina. \\ \mquiroga@inali.unl.edu.ar
}

\begin{abstract}
We studied host use by parasitic botflies (Philornis sp.) in a passerine community in central Argentina and analyzed characteristics of nests and hosts associated with botfly parasitism. We conducted a four-year field study as well as a bibliographical survey where we determined: presence of botfly parasitism, type of nest, presence of green material and small sticks in the nest, average height of the nest, date of last nesting attempt during the breeding season and egg volume (as a surrogate of species body mass). Our field study of 3 birds species showed that botflies parasitized Troglodytes aedon (25\% of nests), but not Sicalis flaveola and Tachycineta leucorroha in spite of nesting in similar boxes, at the same place and during the same time of the year. However T. aedon built nests using dry material while $S$. flaveola and T. leucorroha used green material.The analysis of published data ( 35 species considered) showed a negative association between botfly parasitism and presence of green material in the nest, and a positive association between botfly parasitism and presence of small sticks in the nest and date of the last nesting attempt during the breeding season. Our results indicate that the materials used to build the nest and the extent of the breeding season are factors that influence host use by botflies in central Argentina.
\end{abstract}

Key words: birds, central Argentina, host use, miasis, ectoparasites.

\begin{abstract}
Resumen. Analizamos el uso de hospedadores de moscas parásitas del género Philornis en una comunidad de aves paseriformes en la región centro de Argentina, así como las características de nidos y hospedadores asociadas con el parasitismo de Philornis. Se realizó un estudio de campo de 4 años así como una revisión bibliográfica donde determinamos: presencia de parasitismo de Philornis, tipo de nido, presencia de material verde y pequeñas ramas en el nido, altura promedio del nido, fecha del último intento de nidificación y volumen del huevo (como un estimador de la masa corporal de las especies). Los datos de nuestro estudio de campo mostraron que Philornis parasitó a Troglodytes aedon (25\% de los nidos), pero no nidos de Sicalis flaveola y Tachycineta leucorroha, a pesar de estar nidificando en cajas nidos en un mismo sitio y época del año. Sin embargo, T. aedon utilizó material seco para construir el nido, mientras que S. flaveola y T. leucorroha lo hicieron con material verde. El análisis de la información bibliográfica (35 especies consideradas) mostró una asociación negativa entre el parasitismo de Philornis y la presencia de material verde en el nido y una asociación positiva entre el parasitismo de Philornis y la presencia de pequeñas ramas en los nidos y la fecha del último intento de nidificación en la temporada reproductiva. Nuestros resultados indican que los materiales usados para construir los nidos y la duración de la temporada reproductiva son factores que afectan el uso de hospedadores por parte de Philornis en la región central de Argentina.
\end{abstract}

Palabras clave: aves, región central de Argentina, uso de hospedador, miasis, ectoparásitos.

\section{Introduction}

Nests of alticial birds are microhabitats inhabited by a wide variety of invertebrates (Hicks, 1971; Szabó et al., 2002; Turienzo and Di Iorio, 2007) that find there a source of energetic resources and protection (Majka et al., 2006). Some of these species are external parasites

Recibido: 01 marzo 2011; aceptado: 26 julio 2011 like feather lice (Phthiraptera, Clayton et al., 1999, 2008), mites (Parasitiformes and Acariformes, Proctor and Owens, 2000), fleas (Ceratophyllidae, Tripet and Richner, 1999) and bugs (Hemiptera, Brown and Brown, 2004). Other species, like flies of the genus Philornis (Diptera) are typically subcutaneous parasites (i.e. Texeira, 1999; Spalding et al., 2002).

The genus Philornis (hereafter botflies) comprises approximately 50 species with neotropical distribution (Dodge and Aitken, 1968). This group has special interest 
because their larvae parasitize nestlings establishing different types of associations (coprophagous, semihaematophagous or subcutaneous) and reduce markedly chick survival (i.e. Couri and Carvalho, 2003; Dudaniec and Kleindorfer, 2006). Previous studies on botflies have mostly focused on the impact they produce on host growth and survival (see Dudaniec and Kleindorfer, 2006), and on the influence of some environmental conditions on the frequency of parasitism (Delannoy and Cruz, 1991; Arendt, 2000; Antoniazzi et al., 2010), but to our knowledge, no previous studies have analyzed the pattern of host use by botflies in a passerine community.

Botfly parasitism may be influenced by host characteristics. For example, it has been reported that frequency of botfly parasitism increases as the breeding season advances (Arendt, 1985a, 1985b; Young, 1993; Rabuffetti and Reboreda, 2007) and therefore, early breeder species would have a higher probability to scape parasitism. Similarly, the materials used to build the nest, the type of nest (i.e. open or closed), or its location could also influence the probability of botfly parasitism. Clark (1990) stated that the presence of secondary compounds in green material (leaves) used to build the nest might reduce the probability of ectoparasites (Nest Protection Hypothesis) and some hosts reduce the load of ectoparasites (i.e. blowflies, Ontiveros et al., 2007 or fleas, Shutler and Campbell, 2006) by adding nest material with secondary volatile compounds. Host body mass may also be important for explaining patterns of botfly parasitism as larger hosts can support higher parasite loads (Dudaniec and Kleindorfer, 2006; Dudaniec et al., 2007) and therefore could be preferred by botflies.

The objective of this study is to describe host use by botflies in a passerine community of central Argentina and analyze characteristics of hosts and nests associated with botfly parasitism. Considering the previous information on the interactions between botflies and their hosts we expect a negative association between host use and presence of green material in the nest and a positive association between host use and 1) date of last nesting attempt during the breeding season and 2) body mass of the host.

\section{Materials and methods}

Field study. We collected data on botfly parasitism on 3 potential hosts that nest in cavities (House Wren, Troglodytes aedon, Saffron Finch, Sicalis flaveola, and White-rumped Swallow, Tachycineta leucorroha) at 2 sites near the city of Santa Fe (Argentina), during the breeding seasons (October - February) 2004-2005, 2005-2006, 2006-2007 and 20072008. Site A was located on the campus of University of Litoral $\left(31^{\circ} 38^{\prime} \mathrm{S}, 60^{\circ} 40^{\prime} \mathrm{W}\right)$ and site B at a private cattle ranch about $10 \mathrm{~km}$ away from Site A ( $\left.31^{\circ} 38^{\prime} \mathrm{S}, 60^{\circ} 35^{\prime} \mathrm{W}\right)$.
Study sites were seasonally flooded marsh/woodland areas located at the Paraná River floodplain and surrounded by many watercourses like Setubal lagoon and Colastiné River. Sites included environmental units such as aquatic vegetation, forest, beach and gallery forest where Salix humboltiana, Acacia caven, Tessaria integrifolia, Azola sp., Salvinia sp. and Pistia stratiotes were strongly represented. Mean monthly temperatures for the studied years were $27.6^{\circ} \mathrm{C}$ in January (mid-summer) and $13.9^{\circ} \mathrm{C}$ in July (midwinter). Average annual rainfall at this site was $1083 \pm 54$ $\mathrm{mm}$ (mean \pm SE for the period 1989-2008).

To facilitate data collection we placed 60 and 56 nest boxes at sites A and B, respectively. Boxes were on poles at a height of $1.6 \mathrm{~m}$ and at least $20 \mathrm{~m}$ apart. Their external measurements were $25.4 \times 16.5 \times 17.8 \mathrm{~cm}$ (height, width, depth) and had a $3.8 \mathrm{~cm}$ (in diameter) entrance hole and a lateral opening. We checked nest boxes daily during laying and near the time of hatching, and every 2-3 days during incubation and after hatching. We checked nests until chicks were 12 days of age (House Wren and Saffron Finch) and 15 days of age (White-rumped Swallow). At that time, we stopped physically checking the nests to avoid premature fledging. Each nestling was carefully examined looking for botfly larvae and the day each nest had its first chick infested was registered. We also recorded the material used to build each nest.

At our study site the House Wren and Saffron Finch began laying during early October and continued until earlymid February. Clutch size was 3-5 eggs (modal size $=4$ ) and eggs were incubated for 13-14 days. Nestlings fledged when they were 14-15 days of age (Quiroga, 2009). Whiterumped Swallows began laying during late September and continued until early December. Clutch size was 3-6 eggs (modal size $=5$ ) and eggs were incubated for 13-14 days. Nestlings fledged when they were 20-22 days of age (20042006: Lorenzón 2010; 2007-2008: Quiroga unpublished data).

Bibliographical review. Based on results observed from our field data we decided to test if the observed pattern (see results) was consistent at a community level. We then collected published information of host use by botflies through a bibliographical survey of studies on the breeding biology of passerine species of central Argentina. We did not include our own field data here since it was collected form nest boxes instead of wild nests (as provided by bibliographical data). Because most studies did not identify the parasite to the species level and did not provide data on intensity of parasitism, for our analysis we considered hosts as parasitized by botflies (i.e. flies of the genus Philornis) and did not include intensity of parasitism as a variable. The species of Philornis reported for this region are P. seguyi and P. torquans (Couri et al., 2009). Data on host use were 
obtained from 3 studies conducted in Santa Fe Province (De la Peña et al., 2003; De la Peña 2005, 2010). We obtained additional data from another study conducted by Nores (1995), in Cordoba Province.

Statistical analysis. For our analysis we only included data of species with 5 or more nests with chicks ( $\mathrm{n}=35$ species, Appendix 1). For each species we collected the following information: 1), presence of botflyparasitism $(0 / 1) ; 2)$, type of nest (open or closed, we included dome like and cavity nests in the latter category); 3), presence of green material $(0 / 1)$ and small sticks $(0 / 1)$ in the nest; 4$)$, average height of the nest; 5), date of the last nesting attempt during the breeding season, and 6), volume of host eggs (as a surrogate of host body mass). Egg volumes were calculated based on average values of egg length and width reported by De la Peña $(2005,2010)$ using Hoyt's (1979) formula:

$$
\text { volume }=0.0051 \times \text { length } \times \text { width }^{2}
$$

We used contingency tests to analyze the association between botfly parasitism and presence of green material and small sticks in the nests and type of nest. To analyze the association between botfly parasitism (dichotomous variable) and other continuous variables we performed a logistic regression with presence of botfly parasitism (0/1) as dependent variable and: 1), date of the last nesting attempt during the breeding season (day $0=$ September $15^{\text {th }}$ ); 2), nest height, and 3), egg volume as independent variables. All tests were 2 tailed, and differences were considered significant at $p<0.05$. Reported values are means $\pm \mathrm{SE}$.

\section{Results}

We surveyed 157 House Wren, 62 Saffron Finch and 97 White-rumped Swallow nests. Frequency of parasitism in the House Wren was 25\% and did not differ significantly among years (goodness of fit: $\mathrm{G}_{3}=5.9, p=0.18$ ) or sites (goodness of fit: $\mathrm{G}_{3}=3.37, p=0.07$ ). Botflies parasitized 147 House Wren chicks in 39 nests. We did not detect any evidence of parasitism in the Saffron Finch and the Whiterumped Swallow and no other parasites were found on nestlings or nests of the 3 studied species. The House Wren used dry material (small sticks) to build their nests while the Saffron Finch and the White-rumped Swallow built their nests with green material (swallows also added feathers). Egg morphology and breeding season span of the studied species are shown in Table 1.

Nest boxes were occasionally used by House Sparrows (Passer domesticus). However as a consequence of the low number of cases $(n=8)$ and nest architecture (dome shaped) we decided not to check nestlings in order to avoid destroying the nests.
Table 1. Egg morphology and breeding season span (years 2004 to 2008 combined) of 3 species nesting in nest boxes in central Argentina. Reported values are means $\pm \mathrm{SE}$

\begin{tabular}{lcccccc}
\hline Species & $E L$ & $E W$ & $E M$ & $E V$ & $F N A$ & $L N A$ \\
\hline T. aedon & 17.02 & 12.93 & 1.58 & 1.46 & Sept & Feb \\
& \pm & \pm & \pm & \pm & $9^{\text {th }}$ & $15^{\text {th }}$ \\
& 0.04 & 0.02 & 0.04 & 0.07 & & \\
S. flaveola & 19.08 & 13.86 & 1.97 & 1.871 & Nov & Feb \\
& \pm & \pm & \pm & \pm & $15^{\text {th }}$ & $14^{\text {th }}$ \\
& 0.1 & 0.05 & 0.02 & 0.17 & & \\
T. leucorroha & 20.25 & 14.13 & 2.17 & 2.04 & Sept & Dec \\
& \pm & \pm & \pm & \pm & $26^{\text {th }}$ & $5^{\text {th }}$ \\
& 0.99 & 0.56 & 0.21 & 0.14 & & \\
\hline
\end{tabular}

$\mathrm{EL}=$ egg length $(\mathrm{mm}) . \mathrm{EW}=$ egg width $(\mathrm{mm}) . \mathrm{EM}=$ egg mass (g). $\mathrm{EV}=$ egg volume $\left(\mathrm{cm}^{3}\right)$. FNA= date of first nesting attempt. $\mathrm{LNA}=$ date of the last nesting attempt.

We also analyzed botfly parasitism (whether bird species were parasitized or not) in 35 passerines species belonging to 10 families (Appendix 1), where 11 of them (31\%) were parasitized by botflies, $30(86 \%)$ had open nests and 23 $(66 \%)$ used green material to build the nest. Nest height ranged from 45 to $490 \mathrm{~cm}$, date of the last nesting attempt varied between November 6 and March 14 and egg volume varied between 1.12 and $6.32 \mathrm{~cm}^{3}$.

The proportion of species parasitized with botflies was lower for species with green material in the nest that in those without green material (with: $4 / 23$, without: $7 / 12$, Contingency test, $\chi^{2}=6.13, p=0.01, \mathrm{n}=35$ ). On the contrary, the proportion of species parasitized with botflies was higher in the species with small sticks in the nest than those without small sticks (with: $7 / 11$, without: $4 / 24$, Contingency test, $\chi^{2}=7.72, p=0.005, \mathrm{n}=35$ ). There was no association between botfly parasitism and type of nest (open nests $9 / 30$, closed nests $2 / 5$, Contingency test, $\chi^{2}=0.33, p=0.85, \mathrm{n}=$ 35 ). In addition, there was a positive association between botfly parasitism and date of the last nesting attempt during the breeding season (Logistic regression, $\chi^{2}=4.34, p=0.04$, $\mathrm{n}=35$ [Fig. 1]), but there was no association between botfly parasitism and nest height (Logistic regression, $\chi^{2}=0.35$, $p=0.54, \mathrm{n}=35$ ). With regard to botfly parasitism and host egg volume there was a tendency (although nonsignificant) towards a positive association (Logistic regression, $\chi^{2}=3.2$, $p=0.07, \mathrm{n}=35$ ).

\section{Discussion}

Our field data indicated that despite nesting at the same location, at the same time and in the same type of nest-boxes, botflies parasitized House Wrens, but did not parasitize Saffron Finches and White-rumped Swallows. The main difference between these 3 species is that the 


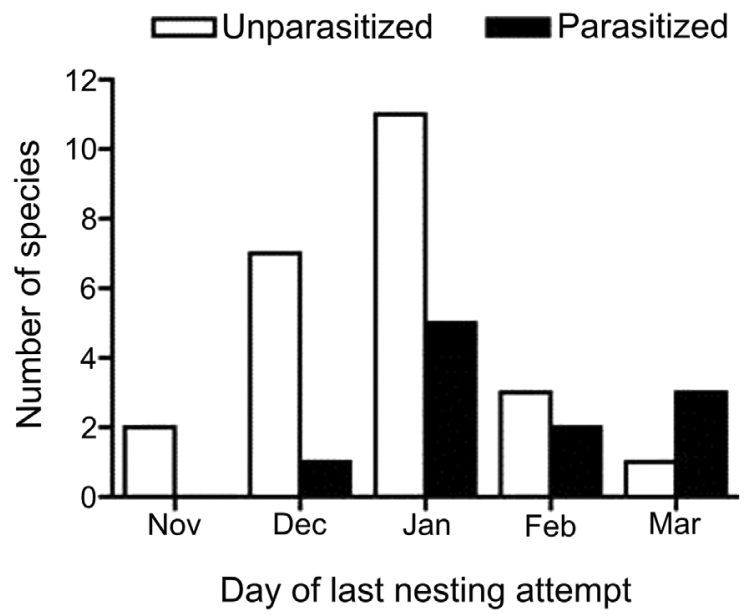

Figure 1. Number of passerine species of a region of central Argentina unparasitized and parasitized by botflies (Philornis spp.) according to the date of the last nesting attempt in the breeding season $(n=35)$.

Saffron Finch and the White-rumped Swallow used green material to build their nests, while the House Wren used small dry sticks. We considered this may be the reason why the first 2 species were not parasitized. Egg morphology and breeding season span data collected from our nest box study was similar to that provided by the bibliographical survey. Prevalence of parasitism in House Wrens $(16.7 \%)$ was slightly higher than that observed by Antoniazzi et al. (2010) for this species in a nearby area and similar to other species (Pitangus sulphuratus: $25 \%$, Paroaria coronata: $20 \%$ and Phacellodomus sibilatrix: 23\%). Studies by Young (1993) of the House Wren in a different geographical area (Costa Rica) and parasitized by another botfly species (P. carinatus), mention an average prevalence of parasitism of $22.1 \%$ (La Lucha: $27.3 \%$, San Luis: 30.6 and Monteverde: 8.4 ), values which are similar to those reported in our study.

As observed in our field study, the analysis of host use by botflies in 35 passerine species of central Argentina also showed a negative association between botfly parasitism and presence of green material in the nest, and a positive association between botfly parasitism and presence of small sticks in the nest. These associations were not independent, as most nests that contained green material did not contain small sticks and viceversa.

In a recent study, Antoniazzi et al. (2010) also described botfly parasitism in a bird community of central Argentina $\left(31^{\circ} 23^{\prime} \mathrm{S}, 60^{\circ} 55^{\prime} \mathrm{W}\right)$. These authors reported 12 species with 5 or more nest records that were parasitized by botflies, 10 of which coincided with those reported in our study.
Our results were consistent with the hypothesis of a repellent effect of green material on ectoparasites (Nest Protection Hypothesis, Clark, 1990), but also with the hypothesis of an attractive effect on botflies of the dry material. In regard to the former hypothesis, several studies have noted that some secondary metabolites present in plants may act as toxins for arthropods (Lozano, 1998; Petit et al., 2002; Dawson, 2004; Shutler and Campbell, 2006). Moreover, experimental work demonstrated that the addition of plants containing secondary volatile compounds to the nest resulted in a marked reduction on the load of mites (Clark and Mason, 1988) and fleas (Shutler and Campbell, 2006). The effect of some secondary compounds has been also tested in laboratory studies, which show that the growth and development of mites are effectively reduced by exposing them to plant species present in nest material (Clark and Mason, 1985). However, because our study is correlational and the presence of green and dry material in the nest are negatively associated, we cannot rule out the hypothesis of an attractive effect of the dry material on botflies.

We also found that species that nested late in the breeding season have a higher probability of botfly parasitism. The same pattern has been found within species (i.e. increase in the frequency of parasitism with time of breeding, Arendt, 1985a, 1985b; Young, 1993; Dudaniec et al., 2007; Rabuffetti and Reboreda, 2007). This association could be the result of seasonal variation in food resources available for adult botflies, or variation in ambient temperature or rainfall (Arendt 1985b, 2000; Delannoy and Cruz, 1991). Alternatively, the increase in frequency of parasitism with time of breeding could be the result of an increase in botfly population. Because hosts are not available during winter it is likely, as observed in other dipterans (i.e. Krafsur et al.,1985; Schmidtmann and Pickens, 1986; Danks, 2006), that botflies have overwintering pupae. This would allow the survival of a few individuals from the end of one breeding season to the beginning of the following one. At that time, a few adults will start to reproduce and, as new adults emerge, the size of botfly population and the frequency of botfly parasitism will increase.

To summarize, our results indicate that the materials used to build the nest and the extent of the breeding season are factors that influence host use by botflies. Further studies on the mechanisms involved in host selection may help us to better understand the population dynamics of these parasites and to predict the impact they may produce on preferred host species. It is also desirable for future studies to consider intensity of infestation (and not just presence/absence and prevalence of parasitism) since this may highly influence chick survival. 


\section{Acknowledgements}

We thank the University Nacional del Litoral (UNL), CERIDE-CONICET and Mr. Francisco Caminos for allowing us to conduct part of this study on their grounds. We also thank L. Auce and R. Lorenzón for field assistance and to R. Regner, E. Lordi and E. Creus (INALI-CONICET-UNL) for setting up and maintaining nest boxes. MAQ was supported by a doctoral fellowship from Consejo Nacional de Investigaciones Científicas y Técnicas of Argentina (CONICET). AHB and JCR are research fellows of CONICET.

\section{Literature cited}

Antoniazzi, L., D. Rohrmann, M. Saravia, L. Silvestri and P. Beldomenico. 2010. Climate variability affects the impact of parasitic flies (Philornis torquans) on Argentinean forest birds. Journal of Zoology 753:1-9.

Arendt, W. 1985a. Philornis ectoparasitism of Pearly-eyed Thrashers I. Impact on growth and development of nestlings. Auk 102:270-280.

Arendt, W. 1985b. Philornis ectoparasitism of Pearly-eyed Thrashers II. Effects on adults and reproduction. Auk 102:281-292.

Arendt, W. 2000. Impact of nest predators, competitors, and ectoparasites on Pearly-eyed Thrashers, with comments on the potential implications for Puerto Rican Parrot recovery. Ornitología Neotropical 11:13-63.

Brown, C. and M. Brown. 2004. Group size and ectoparasitism affect daily survival probability in a colonial bird. Behavioral Ecology and Sociobiology 56:498-514.

Clark, L. 1990. Starling as herbalists: countering parasites and pathogens. Parasitology Today 6:358-360.

Clark, L. and J. Mason. 1985. Use of nest material as insecticidal and antipathogenic agents by the European Starling. Oecologia 67:169-176.

Clark, L. and J. Mason. 1988. Effect of biologically active plants used as nest material and the derived benefit to starling nestlings. Oecologia 77:174-180.

Clayton, D., R. Gregory and R. Price. 1999. Comparative ecology of Neotropical bird lice (Insecta, Phthiraptera). Journal of Animal Ecology 61:781-795.

Clayton, D., R. Adams and S. Bush. 2008. Phthiraptera, the Chewing Lice. In Parasitic diseases of wild birds, T. Atkinson, N. Thomas and B. Hunter (eds.). Wiley-Blackwell, Iowa. p. 515-526.

Couri, M. and C. Carvalho. 2003. Systematic relations among Philornis Meinert, Passeromyia Rodhain and Villeneuve and allied genera (Diptera, Muscidae). Brazilian Journal of Biology 63:223-232.

Couri, M, L. Antoniazzi, P. Beldomenico and M. Quiroga. 2009.
Argentine Philornis Meinert species (Diptera: Muscidae) with synonymic notes. Zootaxa 2261:52-62.

Danks, H. 2006. Short life cycles in insects and mites. Canadian Entomologist 138:407-463.

Dawson, R. 2004. Does fresh vegetation protect avian nests from ectoparasites? An experiment with Tree Swallows. Canadian Journal of Zoology 82:1005-1010.

De la Peña, M., P. Beldomenico and L. Antoniazzi. 2003. Pichones de aves parasitados por larvas de Philornis sp. (Diptera: Muscidae) en un sector de la provincia biogeográfica del Espinal de Santa Fe, Argentina. Revista FAVE - Ciencias Veterinarias 2:141-146.

De la Peña, M. 2005. Reproducción de las Aves Argentinas (con descripción de pichones). Literature of Latin America. Buenos Aires. 846 p.

De la Peña, M. 2010. Nidos de Aves Argentinas. Ediciones Universidad Nacional del Litoral, Santa Fe. CD book.

Delannoy, C. and A. Cruz. 1991. Philornis parasitism and nestling survival of the Puerto Rican Sharp-shinned Hawk. In BirdParasite Interactions. Ecology, evolution and behaviour, J. Loye and M. Zuk (eds.). Oxford University Press, Oxford. p. 93-103.

Dodge, H. and T. Aitken. 1968. Philornis flies from Trinidad (Diptera, Muscidae). Kansas Entomolgical Society 41:134154.

Dudaniec, R. and S. Kleindorfer. 2006. Effects of the parasitic flies of the genus Philornis (Diptera: Muscidae) on birds. Emu 106:13-20.

Dudaniec, R., B. Fessl and S. Kleindorfer. 2007. Interannual and interspecific variation in intensity of the parasitic fly, Philornis downsi, in Darwin's finches. Biological Conservation 139:325-332.

Hicks, E. 1971. Check-list and Bibliography on the Occurrence of Insects in Bird's nest. Supplement II. - Iowa State Journal of Science 46:123-338.

Hoyt, D. 1979. Practical methods of estimating volume and fresh weight of bird eggs. Auk 96:73-77.

Krafsur, E., R. Moon and C. Church. 1985. Age structure and reproductive history of some overwintering face fly (Diptera: Muscidae) populations in North America. Annals of the Entomological Society of America 78:480-87.

Lorenzón, R. 2010. Biología reproductiva de la Golondrina ceja blanca Tachycineta leucorrhoa en el valle de inundación del río Paraná medio, Santa Fe, Argentina. Bachelor dissertation. Facultad de Humanidades y Ciencias, Universidad Nacional del Litoral, Santa Fe. 49p.

Lozano, G. 1998. Parasitic stress and self-medication in wild animals. Advances in the study of behavior 27:291-317.

Majka, C., J. Klimasewski and R. Lauff. 2006. New Coleoptera records from owl nests in Nova Scotia, Canada. Zootaxa 1194:33-47.

Nores, A. 1995. Botfly ectoparasitism of the Brown Cacholote 
and the Firewood-gatherer. Wilson Bulletin107:734-738.

Ontiveros, D., J. Caro and M. Pleguezuelos. 2007. Green plant material versus ectoparasites in nests of Bonelli's eagle. Journal of Zoology 274:99-104.

Petit, C., M. Hossaert-McKey, P. Perret, J. Blondel and M. Lambrechts. 2002. Blue tits use selected plants and olfaction to maintain an aromatic environment for nestlings. Ecology Letters 5:585-589.

Proctor, H. and I. Owens. 2000. Mites and birds: diversity, parasitism and coevolution. Trends in Ecology and Evolution 15:358-364.

Quiroga, M. 2009. Interacciones entre moscas parásitas del género Philornis (Diptera: Muscidae) y su hospedador Troglodytes aedon (Aves: Trogloditidae): ciclo de vida del parásito e impacto sobre el éxito reproductivo del hospedador. Phd. dissertation, Facultad de Ciencias Exactas y Naturales, Universidad de Buenos Aires. 159 p.

Rabufetti, F. and J. Reboreda. 2007. Early infestations by botflies (Philornis seguyi) decreases chick survival and nesting success in Chalk-Browed Mockingbirds (Mimus saturninus). Auk 124:898-906.

Schmidtmann, E. and L. Pickens. 1986. Phenology of diapause induction in a Maryland population of the face fly, Musca autumnalis DeGeer. Journal of Agricultural Entomology 3:297-303

Shutler, D. and A. Campbell. 2006. Experimental addition of greenery reduces flea loads in nests of a non-greenery using species, the Tree Swallow Tachycineta bicolor. Journal of Avian Biology 38:7-12.

Spalding, M., J. Mertins, P. Walsh, K. Morin, D. Dunmore and D. Forrester. 2002. Burrowing fly larvae (Philornis porteri) associated with mortality of Eastern Bluebirds in Florida. Journal of Wildlife Diseases 38:776-783.

Szabó, K., A. Szalmás, A. Liker and Z. Barta. 2002. Effects of haematophagous mites on nestling House Sparrows (Passer domesticus). Acta Parasitologica 47:318-322.

Texeira, D. 1999. Myasis caused by obligatory parasites, Ib. General observations on the biology of species of genus Philornis meinert. In Myasis in man and animals in the Neotropical Region, Guimaraes, J. and N. Papavero (eds.). Pleidae, São Paulo. p. 51-70.

Tripet, F. and H. Richner. 1999. Density-dependent processes in the population dynamics of a bird ectoparasite Ceratophyllus gallinae. Ecology 80:1267-1277.

Turienzo, P. and O. Di Iorio. 2007. Insects found in birds nests from Argentina. Part I: a bibliographical review, with taxonomical corrections, comments and a hypothetical mechanism of transmission of cimicid bugs. Zootaxa 1561:152.

Young, B. 1993. Effects of the parasitic botfly Philornis carinatus on nestling House Wrens, Troglodytes aedon, in Costa Rica. Oecologia 93:256-262.

Appendix 1. List of species unparasitized and parasitized by botflies (Philornis sp.) in a passerine community of central Argentina, and species and nests characteristics. Data were obtained from: a), De la Peña et al. (2003); b), De la Peña (2005); c), De la Peña (2010), and d), Nores (1995). \# nests: number of nests surveyed. Par: absence (0) or presence (1) of Philornis parasitism. Type of nest: open (0) or closed (1) nests. Nest height: average nest height (m). Date: date of the last nesting attempt in the breeding season.

\begin{tabular}{|c|c|c|c|c|c|c|c|c|c|}
\hline Species & Family & \# nests & Par & Type of nest & Nest height & Date & $E V$ & $G M$ & $D M$ \\
\hline Furnarius rufus ${ }^{\mathrm{b}, \mathrm{c}, \mathrm{d}}$ & Furnaridae & 6 & 0 & 1 & 1.86 & 15-Dec & 6.02 & 0 & 0 \\
\hline Pseudoseisura lophotes ${ }^{\mathrm{d}}$ & Furnaridae & 67 & 1 & 0 & 4.9 & 12-Jan & 6.32 & 0 & 1 \\
\hline Certhiaxis cinnamomea $a^{\mathrm{a}, \mathrm{b}, \mathrm{c}, \mathrm{d}}$ & Furnaridae & 5 & 1 & 0 & 1.22 & 16-Jan & 2.2 & 0 & 1 \\
\hline Anumbius annumbi ${ }^{\mathrm{d}}$ & Furnaridae & 50 & 1 & 0 & 2.27 & 2-Jan & 3.88 & 0 & 1 \\
\hline Schoeniophylax phryganophila & Furnaridae & 5 & 1 & 0 & 3.38 & 14-Feb & 2.45 & 0 & 1 \\
\hline Phacellodomus ruber $\mathrm{a,b, \textrm {c } , \mathrm { d }}$ & Furnaridae & 5 & 1 & 0 & 3.71 & 2-Jan & 3.86 & 0 & 1 \\
\hline Phacellodomus sibilatrix ${ }^{\mathrm{b}, \mathrm{c}, \mathrm{d}}$ & Furnaridae & 7 & 0 & 0 & 2.6 & 30-Dec & 2.51 & 0 & 1 \\
\hline Phacellodomus striaticollis ${ }^{\mathrm{b}, \mathrm{c}, \mathrm{d}}$ & Furnaridae & 5 & 0 & 0 & 1.7 & 30-Dec & 3.16 & 0 & 1 \\
\hline Xolmis irupero ${ }^{\mathrm{b}, \mathrm{c}, \mathrm{d}}$ & Tyrannidae & 7 & 0 & 1 & 2.32 & 27-Nov & 3.59 & 0 & 1 \\
\hline Fluvicola albiventer & Tyrannidae & 8 & 0 & 0 & 1.6 & 28-Jan & 1.95 & 1 & 0 \\
\hline Satrapa icterophrys ${ }^{\mathrm{b}, \mathrm{c}, \mathrm{d}}$ & Tyrannidae & 6 & 0 & 0 & 1.96 & 1-Dec & 2.23 & 1 & 0 \\
\hline Pitangus sulphuratus ${ }^{\mathrm{a}, \mathrm{b}, \mathrm{c}, \mathrm{d}}$ & Tyrannidae & 5 & 1 & 0 & 3.56 & 15-Jan & 5.88 & 1 & 0 \\
\hline Tyrannus savana & Tyrannidae & 9 & 0 & 0 & 3.75 & 18-Jan & 2.67 & 1 & 0 \\
\hline Empidonomus aurantioatrocristarus ${ }^{\mathrm{b}, \mathrm{c}, \mathrm{d}}$ & Tyrannidae & 10 & 0 & 0 & 3.47 & 18-Jan & 2.36 & 0 & 1 \\
\hline Sublegatus modestus ${ }^{\mathrm{a}, \mathrm{b}, \mathrm{c}, \mathrm{d}}$ & Tyrannidae & 5 & 1 & 0 & 1.54 & 24-Dec & 1.59 & 1 & 0 \\
\hline
\end{tabular}


Appendix 1. Continues.

\begin{tabular}{|c|c|c|c|c|c|c|c|c|c|}
\hline Species & Family & \# nests & Par & Type of nest & Nest height & Date & $E V$ & $G M$ & $D M$ \\
\hline Myiophobus fasciatus ${ }^{\mathrm{b}, \mathrm{c}, \mathrm{d}}$ & Tyrannidae & 5 & 0 & 0 & 1.28 & $10-F e b$ & 1.78 & 1 & 0 \\
\hline Pyrocephalus rubinus ${ }^{\mathrm{b}, \mathrm{c}, \mathrm{d}}$ & Tyrannidae & 7 & 0 & 0 & 3.1 & 2-Jan & 1.46 & 1 & 0 \\
\hline Elaenia spectabilis ${ }^{\mathrm{b}, \mathrm{c}, \mathrm{d}}$ & Tyrannidae & 9 & 0 & 0 & 3.9 & $14-\mathrm{Feb}$ & 3.28 & 1 & 0 \\
\hline Elaenia parvirostris ${ }^{\mathrm{b}, \mathrm{c}, \mathrm{d}}$ & Tyrannidae & 13 & 0 & 0 & 3.43 & $17-F e b$ & 2.08 & 1 & 0 \\
\hline Tachycineta leucorroha ${ }^{\mathrm{b}, \mathrm{c}, \mathrm{d}}$ & Hirudinidae & 62 & 0 & 1 & 2.41 & 16-Dec & 2.1 & 1 & 0 \\
\hline Troglodytes aedon ${ }^{\mathrm{b}, \mathrm{c}, \mathrm{d}}$ & Troglodytidae & 23 & 1 & 1 & 1.77 & 4-Mar & 1.56 & 0 & 1 \\
\hline Mimus saturninus ${ }^{\mathrm{a}, \mathrm{b}, \mathrm{c}, \mathrm{d}}$ & Mimidae & 19 & 1 & 0 & 2.15 & $1-\mathrm{Feb}$ & 6.28 & 0 & 1 \\
\hline Turdus amaurochalinus ${ }^{\mathrm{b}, \mathrm{c}, \mathrm{d}}$ & Turdidae & 5 & 0 & 0 & 2.98 & 27-Dec & 5.58 & 1 & 0 \\
\hline Turdus rufiventris ${ }^{\mathrm{b}, \mathrm{c}, \mathrm{d}}$ & Turdidae & 5 & 0 & 0 & 3.06 & 18-Jan & 5.91 & 1 & 0 \\
\hline Polioptila dumicola ${ }^{\mathrm{b}, \mathrm{c}, \mathrm{d}}$ & Polioptilidae & 29 & 0 & 0 & 2.19 & 12-Jan & 1.12 & 1 & 0 \\
\hline Saltator aurantiirostris ${ }^{\mathrm{b}, \mathrm{c}, \mathrm{d}}$ & Cardinalidae & 8 & 0 & 0 & 2.73 & 12-Jan & 4.82 & 1 & 0 \\
\hline Paroaria coronata ${ }^{\mathrm{a}, \mathrm{b}, \mathrm{c}, \mathrm{d}}$ & Emberizidae & 14 & 1 & 0 & 3.56 & 14-Mar & 3.31 & 1 & 0 \\
\hline Sporophila caerulescens ${ }^{\mathrm{b}, \mathrm{c}, \mathrm{d}}$ & Emberizidae & 9 & 0 & 0 & 0.52 & 18-Jan & 1.33 & 1 & 0 \\
\hline Sicalis flaveola ${ }^{\mathrm{b}, \mathrm{c}, \mathrm{d}}$ & Emberizidae & 34 & 0 & 1 & 2.75 & 1-Mar & 1.94 & 1 & 0 \\
\hline Zonotrichia capensis ${ }^{\mathrm{b}, \mathrm{c}, \mathrm{d}}$ & Emberizidae & 11 & 0 & 0 & 1.43 & 22-Dec & 2.23 & 1 & 0 \\
\hline Poospiza nigrorufa ${ }^{\mathrm{b}, \mathrm{c}, \mathrm{d}}$ & Emberizidae & 6 & 0 & 0 & 0.45 & 2-Jan & 2.26 & 1 & 0 \\
\hline Poospiza melanoleuca ${ }^{\mathrm{b}, \mathrm{c}, \mathrm{d}}$ & Emberizidae & 5 & 0 & 0 & 1.7 & 27-Nov & 1.75 & 1 & 0 \\
\hline Saltatricula multicolor ${ }^{\mathrm{b}, \mathrm{c}, \mathrm{d}}$ & Emberizidae & 6 & 0 & 0 & 1.35 & 15-Jan & 3.03 & 1 & 0 \\
\hline Icterus cayanensis b,c,d & Icteridae & 6 & 0 & 0 & 3.75 & 25-Jan & 2.99 & 1 & 0 \\
\hline Agelaioides badius ${ }^{\mathrm{a}, \mathrm{b}, \mathrm{c}, \mathrm{d}}$ & Icteridae & 11 & 1 & 1 & 2.59 & 10-Mar & 3.61 & 1 & 0 \\
\hline
\end{tabular}

$\mathrm{EV}=$ average volume of host eggs (cm3). $\mathrm{GM}=$ absence (0) or presence (1) of green material (leaves of different vegetal species) in the nest. $\mathrm{DM}=$ absence $(0)$ or presence $(1)$ of small sticks (dry material) in the nest. 